\title{
Packaging and Branding Strategy to Increase the Competitiveness of Bolu Jadul Business in Bulungan Village, Jepara
}

\author{
Isna Istiqomah, Hefied Adibatul Husna, Khofifatul Lubaba, Ahmad Saefudin, Hudi \\ Pendidikan Agama Islam, FTIK, Universitas Islam Nadhlatul Ulama Jepara \\ E-mail: isnaistiqomah26@gmail.com; hefiedadiba30@gmail.com; \\ khofifatullubaba162@gmail.com; ahmadsaefudin@unisnu.ac.id; shihudi@yahoo.co.id
}

\begin{tabular}{ll}
\hline Article History: & $\begin{array}{l}\text { Abstract: } \text { This community development focuses on } \\
\text { increasing the competitiveness of partners in the home }\end{array}$ \\
Received: Jan $5^{\text {th }} 2021$ & $\begin{array}{l}\text { industry-based processed cake business. The subject of } \\
\text { devotion leads to the development of product quality } \\
\text { Revised: April } 11^{\text {th }} 2021\end{array}$ \\
Accepted: May $30^{\text {th }} 2021$ & with various innovations. The goal is including the lack of \\
& innovation in the marketing process, cake production is \\
still fluctuating and tends to decline, and the appearance & of product packaging is very simple. The Team uses \\
Keywords: business & Participatory Action Research (PAR) as an approach. In \\
competitiveness, packaging, & a participatory manner, the service team encourages \\
pranding strategy, marketing & activities. As a result, in the production sector, partners \\
management. & have succeeded in marketing Jadul Bolu cake products \\
& with online and offline systems. In the field of business \\
management, partners are trained to make packaging or \\
labeling of Bolu Jadul cakes. In the field of marketing, \\
partners utilize internet technology through the use of \\
social media, Instagram.
\end{tabular}

\begin{abstract}
This community development focuses on increasing the competitiveness of partners in the home industry-based processed cake business. The subject of devotion leads to the development of product quality with various innovations. The goal is including the lack of innovation in the marketing process, cake production is still fluctuating and tends to decline, and the appearance of product packaging is very simple. The Team uses Participatory Action Research (PAR) as an approach. In a participatory manner, the service team encourages partners to take transformative actions through various activities. As a result, in the production sector, partners he succeeded in marketing Jadul Bolu cake products management, partners are trained to make packaging or labeling of Bolu Jadul cakes. In the field of marketing, social media, Instagram.
\end{abstract}

\section{Introduction}

Bulungan Village is located in the northeast of the capital city of Jepara Regency with a distance of about $8 \mathrm{KM}$ and is located west of the capital city of Pakis Aji Subdistrict with a distance of about $2.5 \mathrm{KM}$. With an area of $760.543 \mathrm{ha}$, the potential of this village has various potentials ranging from rice fields, dry land, graves, and rivers. Economically, the people of Bulungan Village rely on agriculture, the furniture industry, and the household-based food processing industry.

Therefore, the Service Team chose "Bunda Arum" with the address at Bulungan Tengger, RT 04 RW 02, Pakis Aji District, Jepara as a partner. At the beginning of the journey, "Bunda Arum" started a sewing school business. However, because it was 
considered stagnant and unable to generate profit, the manager moved to the food production sector by opening a catering business called "BUNDA". The group consists of 10 women. After collaborating with the Jepara Regency Government through the Jepara Regency Prosperous Family Income Improvement Effort (UPPKS), the name was changed to "TASYA". The owner's name is Siti Ruminah, who is often called Bunda Arum. The partner's line of business is catering from dry snacks to processed cakes. In completing his work, Mother Arum has a total of 4 members.

The problems faced by partners are low human resources for business management, limited promotion space, lack of innovation in marketing, fluctuating production, and simple product packaging forms. An attractive packaging process and marketing expansion efforts will have an impact on increasing economic profit. ${ }^{1}$ Utilizing social media will also help product promotion more effectively. ${ }^{2}$ Thus, various mastery of individual skills will affect changes in socio-economic status in society. ${ }^{3}$

In terms of quantity, the number of business units in Indonesia has increased from year to year. In 2017 there were 62,928,077 business units and in 2018 it increased to $64,199,606$ business units. This indicates an increase in the number of units by $1,383,299$ units $(2.02 \%)$. A micro business is the largest business scale compared to other businesses to the total business. In 2017 micro-enterprises dominated $98.70 \%$ of the total business, while in 2018 the number of micro-enterprises decreased to $98.68 \%$ of the total business. ${ }^{4}$

Based on the explanation above, we carry out community service activities to help micro-enterprises that are underdeveloped due to a large amount of competition that occurs in the business to accelerate economic and social recovery. Community service in the form of contributing or helping to improve the various needs of the community and solving various problems faced by the community so that the welfare of the community increases which in the end the community can live well, independently, and prosperously. According to law no. 20 of 208 concerning micro, small and medium enterprises are productive economic businesses that stand-alone, which are carried out by individuals or business entities that are not subsidiaries or branches of companies that are owned,

1 Muhammad Nasir and Muhammad Nur, "PKM Pengusaha Bolu Cukke Untuk Pengembangan Usaha Menjadi Usaha Kreatif Rumahan Di Desa Wage Kecamatan Sabbangparu Kabupaten Wajo," Jurnal Pengabdian kepada Masyarakat Sosiosaintifik (JurDikMas) 1, no. 1 (2019): 66.

2 Gusti Ayu et al., "Pelatihan Media Sosial Pada Usaha Kue Di Daerah Batubulan," Jurnal Ilmiah Populer 3, no. 2 (2021): 51.

${ }^{3}$ Sri Rahmayanti et al., "Peningkatan Ketrampilan Dan Manajemen Pemasaran Usaha Rumahan Penghasil Kue Di Kelurahan Sidomulyo," COMSEP: Jurnal Pengabdian Kepada Masyarakat 2, no. 1 (2021): 20.

4 Subagyo, Meningkatkan Daya Saing Dan Kinerja UMKM Tinjauan Dari Perspektif Karakter, Pembelajaran Dan Kompetensi Usaha, (Bandung: Media Sains Indonesia, 2020), 13. 
controlled, or become part of either directly or indirectly medium or large business. ${ }^{5}$

\section{Method}

This service activity is in partnership with the Bulungan Village government. Our target is the owner of the home catering industry. The service that we do in collaboration with a micro-home industry that produces Bolu Jadul cake (traditional cake) at Tasya Catering UMKM in Bulungan village RT 04 RW 02 Pakis Aji District, Jepara Regency has relatively varied business performance with a stagnant tendency. The Bolu Jadul cake is undoubtedly delicious. Based on information from sales partners, old school sponges experienced a decrease in sales volume, due to the globalization era and the 4.0 era where food has undergone various kinds of Western-style modifications.

The contribution of partners in this activity is in the form of providing venue facilities and training equipment. Meanwhile, the service team provides production assistance and conducts marketing training, packaging innovation, and media promotion.

The method of service implementation uses PAR (Participatory Action Research) which consists of three cycles, namely participation, research, and action. These three stages are classified into three areas, including:

\section{Production Field.}

- Prepare materials on cake production to develop Bolu Jadul products together with partners.

- Conducting discussions regarding the needs of partners in carrying out the old school sponge production process.

\section{Management Field}

- Provide knowledge materials and provide insight to partners about entrepreneurial management, the importance of packaging, and labeling of Bolu Jadul cakes.

- Entrepreneurship management training.

- Business management assistance and organizing partners up to packaging and labeling.

${ }^{5}$ Hamdani, Mengenal Usaha Mikro Kecil Dan Menengah (UMKM) Lebih Dekat (Ponorogo: Uwais Inspirasi Indonesia, 2020), 2. 


\section{Marketing Field}

- This stage is the result of an evaluation of entrepreneurial management assistance activities, packaging, and labeling.

- Making packaging and labels that support the marketing of Bolu Jadul cakes.

- Creating an Instagram account as a product promotion medium.

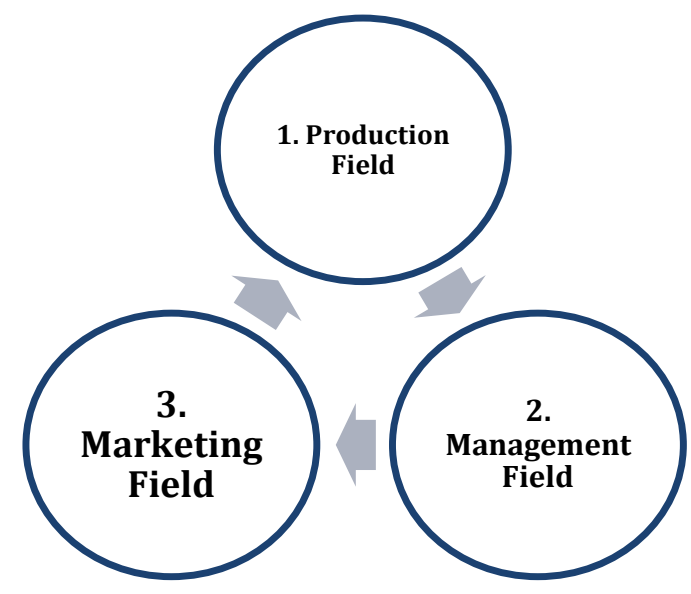

Figure 1. Implementation Methods in Community Service

\section{Result}

Community service regarding the assistance of Bolu Jadul cakes for food security and economic strengthening of the people of Bulungan Village, Jepara Regency during the Covid-19 pandemic has been carried out since February until monitoring and evaluation continues in March 2021. The activity begins with a focus group discussion, training, and assistance. At this stage, a joint discussion stage is carried out regarding the place of activity, the number of people who attend, and the equipment needed by partners in the process of diversifying Bolu Jadul sponge cake products. This activity was carried out at the house of a partner of one of the communities by seeing firsthand how the process of making Bolu Jadul cakes is usually done by the community.

The production stage of the Bolu Jadul cake is carried out at the partner's house, which is located at Bulungan RT 04 RW 02, Pakis Aji District, Jepara Regency. Bolu Jadul cake is a cake made from wheat flour, sugar, and eggs, making old school cakes is the same as making cakes in general, namely by baking in the oven. The ingredients are wheat flour, eggs, milk powder, vanilla, bakery stamp developer, ibis cap softener, margarine. The first way to make it, put 5 eggs in a pan, put 12 tablespoons of sugar into the pan, put 12 
tablespoons of sugar into the pan, stir the eggs that have been mixed with sugar, and valet with a mixer for about 15 minutes, while waiting for the eggs to be stirred with a mixer, put the flour into a container as much as 200 grams, add 1 tablespoon of powdered milk, 1 teaspoon of softener, powder, developer and mix into one.

In this case, the output of community service activities is the development of Bolu Jadul cake products for food security and economic strengthening of the Bulungan Village community, Pakis Aji District during the Covid-19 pandemic. The steps taken are participatory and demonstration. Activities carried out involve participatory partner activities and activities at partner locations. In the activity of assessing the potential of natural resources and the problems found by the partners, the community also takes a role in making assessments, analyzing and evaluating the programs that have been implemented, so that the form of cooperation with partners is not only carried out during activities but can continue. become a target village that other programs can continue to do. So that it becomes a society that can accelerate economic and social recovery.

The results of the interview with a partner named Mrs. Siti Rumina, showed that the priority problems that must be resolved immediately were improving product management, packaging manufacture, and labeling on old school sponge products. In the field of production, the Service Team prepares materials to develop Bolu Jadul cake products together with the Bulungan Village service team which is carried out with partners on how the production process is carried out by partners. Next, discuss the needs of partners in carrying out the Bolu Jadul production process.

The second stage, the Field of Management used, is to provide knowledge or discussion materials and open insight to partners about entrepreneurial management to the importance of packaging or labeling on Bolu Jadul cake products to create interesting Bolu Jadul cakes. This can be seen by the community service team in collaboration with the PKK team, village youth organizations such as youth organizations, IPNU IPPNU, and entrepreneurs in the village as well as business management training to packaging and labeling through the provision of materials and discussions with partners. Business management assistance and organizing up to the manufacture of packaging and labeling.

The third stage, the marketing field, is a step used to evaluate the results of entrepreneurial management assistance, packaging, and labeling which is an element of marketing management by monitoring the realization of packaging and labeling that supports the marketing of Bolu Jadul cakes. For example, by marketing products online or offline. The marketing field is carried out by the community service team through social media, namely Instagram. With the three implementation methods in this service, it can develop a more maximal production business and develop rapidly. 
Mentoring activities in collaboration with Tasya Catering UMKM partnerships overcome the problems faced, namely human resources and promotion are still low, lack of innovation in marketing, fluctuating production and less than optimal production quantities, the packaging is still simple, production sites are less extensive, in production is still there are often rejected products. Micro, Small, and Medium Enterprises (UMKM) have considerable potential to empower growth and development in improving people's lives.
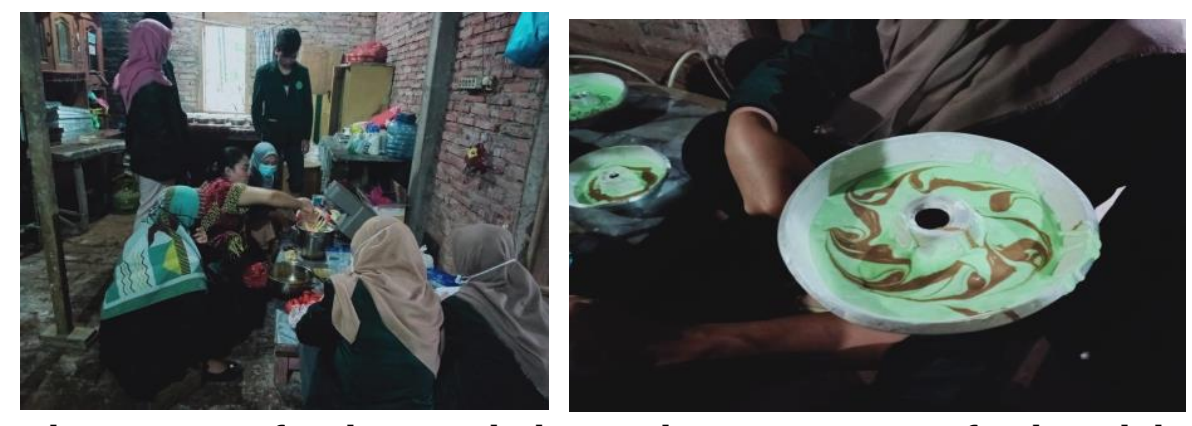

Figure 2. The process of making and The production process of Bolu Jadul cake

As a result, this community service activity can alleviate various problems faced by partners. The collaboration carried out during the activity took place through demonstrations of Bolu Jadul Cake products, making branding, and conducting online and offline marketing techniques. The product demonstration was carried out directly at the house of the production UMKM leader, namely Mrs. Siti Ruminah.

Problems from partner leaders can be resolved gradually through collaboration between the leaders of UMKM partners, village governments, surrounding communities, and partner assistance. The collaborative activities between the teams received appreciation from the field supervisors and the surrounding community. After demonstrating the Bolu Jadul cake product, the partner assistance team conducted marketing through social media and offline with the Cash On Delivery (COD) system to facilitate the expansion of the marketing network. UMKM marketing support is important in addition to capital support. Marketing through information technology has become easier and more efficient for UMKM actors, for that we as a partner assistance team do service to UMKM partners to accelerate economic recovery.

The service team also conducted marketing management socialization involving village entrepreneurs, village youth such as youth organizations, and IPNU-IPPNU. The material in this socialization issues about marketing, types of marketing, good packaging waste management practices, and ways to use social media such as market places and Instagram as marketing sites. After this socialization, it is hoped that it will be useful for partners who participate in the socialization. The result is that both partners make new packaging innovations. In this case, the previous activity was provided with material 
about good packaging, In the next stage, the service team innovated to update packaging, with prepared recipes that used to be made of plastic into the cardboard. The third result is material about the use of social media as marketing. At this stage the service team makes a marketplace for partners, after making this marketplace, it is hoped that it will be able to expand the online marketing network.

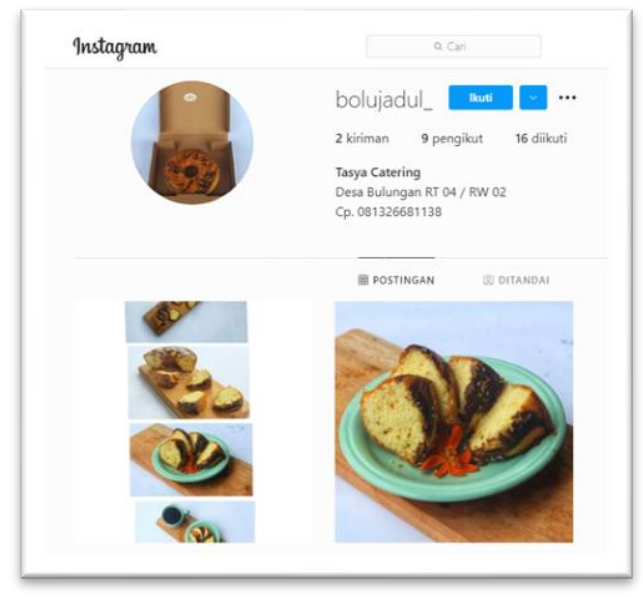

Figure 3. Promotion of Bolu Jadul Cake via Instagram Social Media

\section{Discussion}

Increasing competitiveness is a process of increasing product excellence and partner quality with various innovations. ${ }^{6}$ One of the efforts made by the Service Team to increase the competitiveness of partners is to package the Bolu Jadul cake so that it looks more attractive to consumers. Because innovative packaging affects product quality. ${ }^{7}$

The service team chose Tasya Catering because the partner was still experiencing problems in several aspects such as the lack of partner knowledge about how to do good and the right marketing, less attractiveness in the product packaging process, and the lack of use of social media. In addition, in the production process, product quality management is relatively ineffective and efficient, health standards in the production process tend to have not received serious attention. Cake sales activities like this need to be supported by attractive packaging in terms of shape, color, material, packaging design that can affect consumers or packaging that has a category killer to win the competition. Traditional cakes are sold in simple packaging (clear plastic and hot adhesive or rubber, product presentation and packaging have no value) and relatively do not guarantee product hygiene. This condition tends or relatively places traditional cake products only Brawijaya.

${ }^{6}$ Hariadi, 2005, Strategi Manajemen, Malang: Pusat Pengembangan Akuntansi Universitas

${ }^{7}$ Marliana S.Palad and Rosnida, "Upaya Peningkatan Kualitas Dan Produktivitas Kue Tradisional Bolu Cukke Di Lappa-Sinjai," in Seminar Nasional LP2M UNM, vol. 2, 2017, 364. 
as products sold in traditional markets and is not competitive.

This condition is contradictory to the current fact, namely the increasingly intense competition in the culinary business, and the consequences of this condition require traditional cake business actors such as being smart to find ways so that their products continue to be sought by consumers. Consumer behavior that is increasingly critical of product packaging, especially for food product packaging, must receive special attention. Ideally, packaging using materials that are environmentally friendly, easy to carry, and safe and does not cause contamination of cakes, and providing adequate product information will be the choice of consumers. In addition to these factors, you must also pay attention to what is the trend in society. Traditional cake packaging that is not up-todate will give the impression that the traditional cake product is outdated.

So, social media is needed as a product marketing instrument. However, the marketing process by utilizing social media accounts will affect consumer buying interest. 8

Building a community is one form of the dharma of higher education in Indonesia. As educational institutions, universities do not exist in a vacuum, but universities must be in touch with the dynamics of society, both at the micro and macro levels. ${ }^{9}$ That way, universities must realize concern for the community through community service programs. One of them is to assist at home industry-based processed cake entrepreneurs.

\section{Conclusion}

Community service activities in partnership with Tasya Catering focus on the areas of production, entrepreneurial management, and marketing. In the field of production, the Service Team and partners increase the volume of making Jadul Bolu cakes. In the field of entrepreneurial management, entrepreneurship training was carried out which was attended by stakeholders in Bulungan Village such as food processing business players, Karang Taruna, and IPNU-IPPNU. In the field of marketing, the Service Team helps partners to market products online through Instagram social media.

The implementation of the packaging strategy is an applicative concept that is a determinant in increasing the competitiveness of traditional cake products (Bolu Jadul). Implementation of packaging strategies to change and adjust the perspective of

\footnotetext{
${ }^{8}$ Giri Maulana Arief and Heppy Millianyani, "Pengaruh Social Media Marketing Melalui Instagram Terhadap Minat Beli Konsumen Sugar Tribe," in E-Proceeding of Management :, vol. 2, 2015, 2586.

${ }_{9}$ Umi Hanifah, Puji Alawiyah, and Aulia Agustin, "Pengembangan Ekonomi Masyarakat Melalui Program Diversifikasi Olahan Makanan Berbahan Dasar Jagung Di Desa Mategal Kecamatan Parang Kabupaten Magetan," Engagement: Jurnal Pengabdian Kepada Masyarakat 4, no. 2 (2020): 4-5.
} 
entrepreneurs and the attitude of old school sponge entrepreneurs as "the real service company" for their consumers to win the level of competition and gain consumer loyalty. The packaging strategy is an added value to the product and ultimately adds to the competitiveness of the product.

It is hoped that the manager of the Jadul Bolu cake business will continue to adapt to the increasingly competitive atmosphere of the industrial world. Can continue to innovate through the implementation of attractive packaging strategies and utilize information technology in developing creativity in a sustainable manner.

\section{Acknowledgements}

On this occasion, the Community Service Team thanked those who have supported the success of mentoring and community service in Bulungan Village, Pakis Aji District, Jepara Regency. Among them is the Institute for Research and Community Service (LPPM) of the Islamic University of Nadhlatul Ulama Jepara which has made efforts to succeed in community service programs by students and lecturers, the Bulungan village government which has gladly accepted the service team with all forms of community service activities that have been launched. We do not forget to thank the Field Advisory Lecturer (DPL) of the Real Work Lecture Program (KKN) of the Islamic University of Nadhlatul Ulama Jepara who has provided guidance and direction. Thus, the entire process of community service activities runs successfully and smoothly.

\section{Reference}

Arief, Giri Maulana, and Heppy Millianyani. "Pengaruh Social Media Marketing Melalui Instagram Terhadap Minat Beli Konsumen Sugar Tribe." In E-Proceeding of Management :, 2:2581-2587, 2015.

Ayu, Gusti, Desi Saryanti, I Gusti Ngurah, Adi Kusuma, Komang Tamia Parameswari, I Gusti Bagus, Putra Sidhiantara, I Gusti Ayu, Putri Indah, and Rosalia Hadi. "Pelatihan Media Sosial Pada Usaha Kue Di Daerah Batubulan.” Jurnal Ilmiah Populer 3, no. 2 (2021): 49-53.

Hamdani. Mengenal Usaha Mikro Kecil Dan Menengah (UMKM) Lebih Dekat. Ponorogo: Uwais Inspirasi Indonesia, 2020.

Hanifah, Umi, Puji Alawiyah, and Aulia Agustin. "Pengembangan Ekonomi Masyarakat Melalui Program Diversifikasi Olahan Makanan Berbahan Dasar Jagung Di Desa Mategal Kecamatan Parang Kabupaten Magetan." Engagement: Jurnal Pengabdian Kepada Masyarakat 4, no. 2 (2020): 363-375.

Nasir, Muhammad, and Muhammad Nur. "PKM Pengusaha Bolu Cukke Untuk 
Pengembangan Usaha Menjadi Usaha Kreatif Rumahan Di Desa Wage Kecamatan Sabbangparu Kabupaten Wajo." Jurnal Pengabdian kepada Masyarakat Sosiosaintifik (JurDikMas) 1, no. 1 (2019): 64-69.

Rahmayanti, Sri, Misral Misral, Siti Hanifa Sandri, Hendri Ali Ardi, Bakaruddin Bakaruddin, Norra Isnasia Rahayu, and Jeki Algusri. "Peningkatan Ketrampilan Dan Manajemen Pemasaran Usaha Rumahan Penghasil Kue Di Kelurahan Sidomulyo." COMSEP: Jurnal Pengabdian Kepada Masyarakat 2, no. 1 (2021): 15-20.

S.Palad, Marliana, and Rosnida. "Upaya Peningkatan Kualitas Dan Produktivitas Kue Tradisional Bolu Cukke Di Lappa-Sinjai." In Seminar Nasional LP2M UNM, 2:364-366, 2017.

Subagyo. Meningkatkan Daya Saing Dan Kinerja UMKM Tinjauan Dari Perspektif Karakter, Pembelajaran Dan Kompetensi Usaha,. Bandung: Media Sains Indonesia, 2020. 